\title{
In Vitro Inhibition of Adult Rat Intestinal Heme Oxygenase by Metalloporphyrins ${ }^{1}$
}

\author{
HENDRIK J. VREMAN, MICHAEL J. GILLMAN. AND DAVID K. STEVENSON \\ Department of Pediatrics, Stanford University School of Medicine, Stanford California 94305
}

\begin{abstract}
We determined the inhibitory effects of concentrations of tin- and zinc protoporphyrin (1-100 $\mu \mathrm{M})$ and mesoporphyrin $(0.1-10 \mu \mathrm{M})$ on the in vitro heme oxygenase (HO) (E.C.1.14.99.3) activity in liver, spleen, and intestine 13, $000 \times g$ tissue supernatants from fasted adult male Wistar rats through measurement of carbon monoxide by gas chromatography. All four metalloporphyrins inhibited intestinal $\mathrm{HO}$, under the light-limited conditions of these experiments. The zinc porphyrins showed a clear concentration dependency over the entire range, reducing activity to near zero levels at their highest concentrations. The tin porphyrins reduced $\mathrm{HO}$ activity to $26 \%$ of initial levels, but the inhibition was not clearly concentration dependent. Liver and spleen supernatants exhibited concentration dependent inhibition by all four metalloporphyrins. We also assessed the effect of light on $\mathrm{HO}$ activity measurements. $\mathrm{HO}$ determinations in the light $\left(8 \mu \mathrm{W} / \mathrm{cm}^{2} / \mathrm{nm}\right)$ yielded higher HO activity than for reactions performed in the dark. The presence of light and SnPP appeared to stimulate the $\mathrm{HO}$ activity of intestinal preparations thus overcoming the observed inhibition. Light and SnPP also decreased to a lesser degree the inhibition for the spleen preparation, but not for the liver. We conclude that heme oxygenase activity measurements via $\mathrm{CO}$ determination need to be conducted in the absence of light, in particular when photosensitizers are present. Furthermore, it appears that intestinal $\mathrm{HO}$ behaves in a quantitatively different way from other tissues, under varying conditions of metalloporphyrin inhibition and light exposure. (Pediatr Res 26:362-365, 1989)
\end{abstract}

\section{Abbreviations}

HO, heme oxygenase

ZnPP, zinc protoporphyrin

ZnMP, zinc mesoporphyrin

SnPP, tin protoporphyrin

SnMP, tin mesoporphyrin

Jaundice, a problem common to the human neonate, results from increased bilirubin production and immaturity of the bilirubin-conjugating mechanism in the liver. $\mathrm{HO}$, the rate-limiting enzyme (E.C.1.14.99.3) in the heme catabolic pathway, cleaves

Received December 8, 1988; accepted June 2, 1989. Correspondence and reprint requests to David K. Stevenson, M.D., Department of Pediatrics, Stanford University School of Medicine, Stanford, CA 94305.

Supported in part by the Mead Johnson Nutritional Division, the Christopher Taylor Harrison Research Fund, and Grant HD14426 from the National Institutes of Health.

${ }^{1}$ Patent disclosure: Hendrik J. Vreman, Ph.D. and David K. Stevenson, M.D. have been issued U.S. Patent no. 4,831,024 for Method to Prevent Neonatal Jaundice, involving a screening procedure to detect elevated bilirubin production by $\mathrm{CO}$ detection technology combined with metalloporphyrin therapy. and oxidizes the $\alpha$-methene bridge of the heme molecule, yielding $\mathrm{CO}$, iron, and biliverdin in equimolar amounts (1). Biliverdin is rapidly converted to bilirubin by the enzyme biliverdin reductase.

SnPP and ZnPP, synthetic heme analogs (Fig. 1), have been shown to be effective in lowering serum bilirubin levels in a wide range of animal species (2-8), by competitively inhibiting heme oxygenase activity (7-10). Additionally, SnMP and ZnMP have recently been found to be equally effective at about 10 -fold lower doses $(11,12)$.

Previous studies have shown that heme is excreted into the bile of SnPP-treated adult rats $(13,14)$. Inhibition of intestinal $\mathrm{HO}$ may be of clinical importance, because heme reaching the intestine can potentially be degraded by intestinal tissue $\mathrm{HO}$ (1518) to $\mathrm{CO}$ and bilirubin, where the latter may enter the body via the enterohepatic circulation in the neonate (19). Previously we did not observe significant inhibition of intestinal $\mathrm{HO}$ in vivo or in vitro at SnPP concentrations $(40 \mu \mathrm{M})$ which inhibited hepatic and splenic HO $(18,20-21)$. We could not explain this lack of inhibition, but considered the existence of an isoform of $\mathrm{HO}$ (22), specific to the intestine, which is relatively less inhibitable by SnPP or some mechanism (natural or experimental) by which access of SnPP to HO is limited or by which extraneous $\mathrm{CO}$ is generated. Although our gas chromatographic assay for $\mathrm{HO}$ activity measures the generation of $\mathrm{CO}(23)$, a nonlight-sensitive product of the $\mathrm{HO}$ reaction, we had observed the generation of extraneous CO from tissues treated with SnPP and light (24). Therefore, we studied the in vitro efficacy of SnPP and ZnPP, as well as their mesoderivatives, to inhibit adult rat intestinal $\mathrm{HO}$ in $13000 \times g$ tissue homogenate supernatants over a wide range of concentrations $(0.1,1,10,40$, and $100 \mu \mathrm{M})$ and light exposure. Liver and spleen tissue preparations were used as controls to demonstrate the efficacy of the various metalloporphyrins to decrease $\mathrm{HO}$ activity in tissues known to be inhibitable.

\section{MATERIALS AND METHODS}

Animals. This protocol was approved by the research committee of the Stanford University Division of Laboratory Animal Medicine. Fasted $(16 \mathrm{~h})$ adult male Wistar rats (Simonsen Laboratories, Inc., Gilroy, CA) weighing 265-310 $\mathrm{g}$ were used for all experiments. The rats had unlimited access to water and were housed in a temperature-controlled room $\left(25 \pm 1^{\circ} \mathrm{C}\right)$ with a 12 $\mathrm{h}$ light cycle starting at $0700 \mathrm{~h}$. All animals were killed by decapitation at the conclusion of each experiment.

Buffer, $0.1 \mathrm{M} . \mathrm{KH}_{2} \mathrm{PO}_{4}, 13.61 \mathrm{~g}$ was dissolved in distilled water. The pH was titrated to 7.4 with $1.0 \mathrm{~N} \mathrm{KOH}$ and the volume was adjusted to 11 .

Metalloporphyrins. Stock solutions of $3.0 \mathrm{mM}$ for the protoporphyrins, and $0.3 \mathrm{mM}$ for the mesoderivatives, were prepared by dissolving SnPP (22.4 mg), ZnPP (18.7 mg), SnMP (2.25 mg) and ZnMP (1.89 mg) (Porphyrin Products Inc., Logan, UT) in $0.5 \mathrm{~mL}$ of $10 \%(\mathrm{v} / \mathrm{v})$ ethanolamine (Sigma Chemical Co., St. Louis, MO). Human serum albumin (100 mg, fraction V, no. A1653, Sigma) was added, and the $\mathrm{pH}$ of all solutions was slowly 


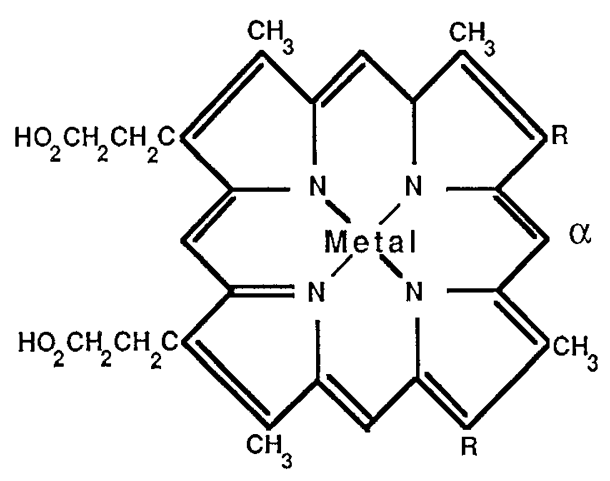
Metals:
1. Fe-Heme
2. Sn-Tin Metalloporphyrin
3. Zn-Zinc Metalloporphyrin
R-Chemical Group:
1. Protoporphyrin, $\mathrm{R}=\mathrm{Vinyl}\left(\mathrm{CH}_{2} \mathrm{CH}-\right)$
2. Mesoporphyrin, $\mathrm{R}=$ Ethyl $\left(\mathrm{CH}_{3}-\mathrm{CH}_{2}\right)$

Fig. 1. Chemical structure of the metalloporphyrins studied.

titrated with a manual titrator (Gilmont, Cole-Parmer Instrument Co., Chicago, IL) under stirring to 7.4 with $1.0 \mathrm{~N} \mathrm{HCl}$. The final volume was then adjusted to $10 \mathrm{~mL}$. Solutions were kept in the dark at $4^{\circ} \mathrm{C}$ and used within 2 wk of preparation. Inhibitor working solutions were prepared by appropriately diluting the stock solutions with buffer so that $2 \mu \mathrm{L}$ added to 60 $\mu \mathrm{L}$ reaction mixture yielded the desired final concentration of 0.1 to $100 \mu \mathrm{M}$.

Methemalbumin, $150 / 11.2 \mu M$. Hemin (13.1 mg, Sigma) was dissolved in $2.5 \mathrm{~mL}$ of $0.4 \mathrm{M} \mathrm{Na}_{3} \mathrm{PO}_{4}$. Distilled water $(6.5 \mathrm{~mL})$ and $100 \mathrm{mg}$ BSA (fraction V, no. A4503, Sigma) were added. The $\mathrm{pH}$ of the solution was slowly titrated to 7.4 with $1.0 \mathrm{~N} \mathrm{HCl}$ under stirring. The volume of this stock solution $(2 / 0.15 \mathrm{mM})$ was adjusted to $10 \mathrm{~mL}$ with distilled $\mathrm{H}_{2} \mathrm{O}$. The stock solution was stored at $4^{\circ} \mathrm{C}$ in the dark for up to $1 \mathrm{mo}$. The working solution was obtained by diluting $(0.75$ to $10.0 \mathrm{~mL})$ the stock solution with buffer.

NADPH, $4.5 \mathrm{mM}$. Four mg NADPH, tetrasodium salt $(8.5 \%$ $\mathrm{H}_{2} \mathrm{O}$ ), type 1 (Sigma) was dissolved in $1.0 \mathrm{~mL}$ buffer. This solution was prepared fresh daily.

Tissue collection and preparation. Tissue supernatants were prepared for assay as follows. Organs were removed immediately from the decapitated animal and washed with ice-cold buffer. Liver and spleen were homogenized (20 s) with a Biohomogenizer (Biospec Products, Inc., Bartlesville, OK) in buffer (4 and 9 $\mathrm{mL} / \mathrm{g}$, respectively). The intestine was cut at the pyloric sphincter and at the anus. The entire length was flushed with $40 \mathrm{~mL}$ of ice-cold buffer to remove all intestinal contents. The tissue was homogenized with buffer $(4 \mathrm{~mL} / \mathrm{g})$. Homogenates were centrifuged at $13000 \times g$ for $15 \mathrm{~min}$ at $4^{\circ} \mathrm{C}$. The supernatants were analyzed for $\mathrm{HO}$ activity.

HO assay. The $\mathrm{HO}$ activity of tissue supernatants was determined with the gas chromatographic assay which measures the amount of $\mathrm{CO}$ produced from heme in the presence of NADPH, as described in detail elsewhere (23). Twenty $\mu \mathrm{L}$ supernatant, 20 $\mu \mathrm{L}$ methemalbumin solution ( $50 \mu \mathrm{M}$ final concentration), and either $20 \mu \mathrm{L}$ of NADPH (for total reaction) or buffer (for blank reaction) were pipetted into duplicate septum-sealed amber vials $(12 \times 32 \mathrm{~mm}, 2 \mathrm{~mL}$, Alltech Associates, Inc., San Jose, CA). For inhibitor testing reactions, small volumes $(2 \mu \mathrm{L})$ of SnPP and ZnPP working solutions were added to yield 1.0, 10, 40, and 100 $\mu \mathrm{M}$ concentrations. The meso derivatives, SnMP and ZnMP, were aliquoted to give $0.10,1.0,4.0$, and $10 \mu \mathrm{M}$ concentrations. After temperature equilibration in a $37^{\circ} \mathrm{C}$ waterbath for $5 \mathrm{~min}$, the vial headspace was purged with $\mathrm{CO}$-free air. The reaction was continued for $15 \mathrm{~min}$ at $37^{\circ} \mathrm{C}$. Enzyme activity was terminated by quick-freezing the vial in a dry ice-acetone bath $\left(-78^{\circ} \mathrm{C}\right)$. The $\mathrm{CO}$ produced in the vial head space was then quantified by gas chromatography using $\mathrm{CO}$ in $\mathrm{N}_{2}$ as a standard as described previously. The entire assay was carried out in the dark.

We assessed the effect of light on $\mathrm{HO}$ activity determinations by performing the HO assay according to the procedure outlined above, except that the reactions were carried out in clear glass vials, which were placed in a water bath with a clear plexiglass bottom. One cool white fluorescent tube (T20T12CW, Philips, Inc., Salem, MA), emitting radiation primarily between 450-700 $\mathrm{nm}$, was placed below the water bath so that the vial bottoms were exposed to a radiance of $8 \mu \mathrm{W} / \mathrm{cm}^{2} / \mathrm{nm}$ as measured with a Bili Meter (Olympic Medical, Seattle, WA). The vials were exposed to the light only during the 15 -min reaction period.

Protein determination. The protein concentration of supernatant was determined by the method of Lowry et al. (25), using BSA as the standard

Statistics. All data are expressed as mean $\pm \mathrm{SD}$. For intergroup comparisons (Table 1), the null hypothesis that there was no difference between the groups of a given tissue preparation at any concentration was tested by using one-way analyses of variance. Statistical difference between each concentration and the control was tested by using the Bonferroni multiple comparions $t$ test. Student's $t$ test for independent and paired samples was used for statistical analysis of the results in Table 2 . Differences with $p<0.05$ were considered to be significantly different.

\section{RESULTS}

The results of in vitro addition of various concentrations of metalloporphyrins on the activity of heme oxygenase in the intestine, liver, and spleen $13000 \times g$ supernatants are summarized in Table 1 . The null hypothesis that there was no difference between the groups of a given tissue preparation at any concentration was rejected with a $p<10^{-6}$ for all tissues. The data show that $1 \mu \mathrm{M}$ ZnPP significantly $(p<0.001)$ inhibited (to $47 \%$ ) adult rat intestinal $\mathrm{HO}$ activity from $0.19 \pm 0.04$ to $0.09 \pm 0.04 \mathrm{nmol} \mathrm{CO} / \mathrm{h} / \mathrm{mg}$ protein. Furthermore, increased ZnPP concentrations progressively inhibited $\mathrm{HO}$ activity to completeness. A similar pattern was observed for ZnMP, but the inhibition was not complete at $10 \mu \mathrm{M}$. Both SnPP and SnMP significantly inhibited intestinal $\mathrm{HO}$ activity at all of the concentrations tested, but this inhibition was not clearly concentration dependent over the range examined. All of the metalloporphyrins significantly inhibited hepatic and splenic $\mathrm{HO}$ activity, even at the lowest concentration evaluated. The degree of inhibition tended to increase with increasing concentration.

Table 2 compares the results of $\mathrm{HO}$ activity measurements performed in the dark versus the light on intestine, liver, and spleen $13000 \times g$ supernatants. HO determinations in the light $\left(8 \mu \mathrm{W} / \mathrm{cm}^{2} / \mathrm{nm}\right)$ in the absence of added metalloporphyrin (+ buffer only) yielded higher values for intestine (122\%), liver $(123 \%)$, and spleen $(153 \%)$ than for reactions performed in the dark. When SnPP was added and determinations were performed under dark conditions, significant inhibition of all preparations by $40 \mu \mathrm{M}$ SnPP was observed. Liver and spleen were nearly completely inhibited and intestine was inhibited by nearly $50 \%$. Light $\left(8 \mu \mathrm{W} / \mathrm{cm}^{2} / \mathrm{nm}\right)$ appeared to stimulate the $\mathrm{HO}$ activity of the intestinal preparation exposed to SnPP, completely overcoming the inhibition observed in the dark. A similar effect, although 
Table 1. Adult rat tissue intestinal heme oxygenase activity in $13000 \times g$ supernatant compared to that of liver and spleen and inhibition by various metalloporphyrins in vitro; only intestinal preparation was studied at $40 \mu \mathrm{M}$ concentration

\begin{tabular}{lrrcc}
\hline \multirow{2}{*}{ Treatment } & \multicolumn{3}{c}{ Heme oxygenase activity $(\mathrm{nmol} \mathrm{CO} / \mathrm{h} / \mathrm{mg}$} \\
protein)
\end{tabular}

Statistical significance when compared to the control: Bonferroni $t$ test: ${ }^{*} p<0.001 ; \dagger p<0.01 ; \ddagger p<0.0005 ; \S p<0.005$.

Table 2. Adult rat intestinal, hepatic, and splenic heme oxygenase activity in $13000 \times g$ supernatant, and inhibition by $40 \mu M$ SnPP determined in light $(8 \mu \mathrm{W} / \mathrm{cm} 2 / \mathrm{nm})$ compared to determinations performed in dark

\begin{tabular}{|c|c|c|}
\hline \multirow[b]{2}{*}{ Tissue } & \multicolumn{2}{|c|}{$\begin{array}{l}\text { Heme oxygenase activity (nmol } \\
\mathrm{CO} / \mathrm{h} / \mathrm{mg} \text { protein) }\end{array}$} \\
\hline & Dark & Light \\
\hline \multicolumn{3}{|l|}{ Intestine $(n=6)$} \\
\hline+ buffer & $0.23 \pm 0.05$ & $0.28 \pm 0.15$ \\
\hline$+40 \mu \mathrm{M} \mathrm{SnPP}$ & $0.14 \pm 0.06^{*}$ & $0.69 \pm 0.31^{*}$ \\
\hline \multicolumn{3}{|l|}{$\operatorname{Liver}(n=3)$} \\
\hline+ buffer & $0.34 \pm 0.12$ & $0.42 \pm 0.1$ \\
\hline$+40 \mu \mathrm{M}$ SnPP & $0.04 \pm 0.01$ & $<0.01^{*}$ \\
\hline \multicolumn{3}{|l|}{ Spleen $(n=3)$} \\
\hline+ buffer & $1.26 \pm 0.39$ & $1.93 \pm 0.51$ \\
\hline$+40 \mu \mathrm{M} \mathrm{SnPP}$ & $<0.01^{*}$ & $1.31 \pm 0.16$ \\
\hline
\end{tabular}

Statistical significance when compared to the buffer control: Student's paired $t$ test: $* p<0.05$.

smaller in magnitude was observed for the spleen preparation. Light and SnPP did not appear to affect the inhibition of liver $\mathrm{HO}$ activity. The presence of light did not significantly affect the inhibition by $40 \mu \mathrm{M} \mathrm{ZnPP}$ which was observed in intestine, liver, or spleen preparations [intestine $(n=6) 0.23 \pm 0.50 \mathrm{nmol} \mathrm{CO} /$ $\mathrm{h} / \mathrm{mg}$ protein versus $0.11 \pm 0.06(p<0.05)$; liver $(n=3) 0.34 \pm$ 0.12 versus $0.02 \pm 0.01(p<0.05)$; spleen $(n=3) 1.26 \pm 0.39$ versus $<0.01 \mathrm{nmol} \mathrm{CO} / \mathrm{h} / \mathrm{mg}$ protein $(p<0.05)]$.

\section{DISCUSSION}

This is the first report to demonstrate that metalloporphyrins can significantly inhibit adult rat intestinal $\mathrm{HO}$ activity in vitro. Previous studies on our laboratory $(18,20,21)$ could not demonstrate significant in vitro inhibition of intestinal $\mathrm{HO}$ in 13000 $\times g$ supernatants of tissue homogenates from adult rats by concentrations of SnPP as high as $100 \mu \mathrm{M}$. This finding was a glaring exception for the intestine compared with other tissues, such as liver and spleen, which were dramatically inhibited under similar reaction conditions. Although no clear pattern of in vitro inhibition of intestinal $\mathrm{HO}$ could be demonstrated previously at $40 \mu \mathrm{M} \mathrm{ZnPP}$, the standard deviation was large (36\%), and the results of some individual experiments suggested that $\mathrm{ZnPP}$ was inhibiting intestinal HO. In fact, a higher dose of ZnPP $(100 \mu \mathrm{M})$ appeared to inhibit intestinal $\mathrm{HO}(21)$. Considering our results with tin protoporphyrin $(18,20,21)$, we questioned this finding and further queried whether conditions peculiar to intestinal tissue itself or to our experimental procedure could have influenced the results. Our findings suggest that both possibilities may have played a role and show that all four metalloporphyrins tested can significantly inhibit intestinal $\mathrm{HO}$ activity (as measured by $\mathrm{CO}$ generation) in vitro, at concentrations as low as 1 $\mu \mathrm{M}$, under strictly light-limited conditions. The control tissues, liver and spleen were also significantly inhibited by the lowest concentrations $(1 \mu \mathrm{M}$ protoporphyrin and $0.1 \mu \mathrm{M}$ mesoporphyrin) of the metalloporphyrins tested.

We were especially intrigued by the apparent difference between SnPP and ZnPP with respect to their capacity to generate $\mathrm{CO}$ from intestinal tissue in the presence of light. We would have expected similar capacities based on photophysical properties alone (26), but ZnPP appears to be much less photoreactive in physiologic environments (27). We knew that SnPP had been reported to be a strong photosensitizer (26-28). However, during the development phase of our HO assay (23), no evidence had been presented in the literature that $\mathrm{CO}$ could be a reaction product of SnPP-mediated photooxidation. Because the gas chromatographic method measures light-stable $\mathrm{CO}$ as the direct product of the HO reaction, we had initially not been particularly concerned about ambient light levels. The latter is, of course, a serious concern when light-sensitive bilirubin production is measured as a basis of $\mathrm{HO}$ activity determination by spectrophotometry techniques (1). The report by McDonagh and Palma (29) on SnPP-enhanced photooxidation of bilirubin in vitro is of particular relevance only to the spectrophotometric determination of HO activity. However, we recently discovered that SnPP, more readily than $\mathrm{ZnPP}$, supports generation of $\mathrm{CO}$ from organic molecules exposed to cool white light in vitro (24). The apparent lack of inhibition of intestinal HO by SnPP can now be explained on the basis of the effect that light has on CO-based HO determinations in the presence of SnPP. This phenomenon is less prominent with ZnPP, which accounts most likely for ability of $\mathrm{ZnPP}$ to inhibit intestinal $\mathrm{HO}$ at light fluxes capable of overcoming inhibition by SnPP. It is not possible to estimate, in retrospect, the light quality and intensity encountered during the previous studies $(18,20,21)$, but our results indicate that the previously observed lack of inhibition of intestinal HO with SnPP could be explained by the fact that HO activity determinations were performed under ambient light (a mixture of indirect summer daylight and cool white fluorescent light ranging in radiant flux from 0.5 to approximately $5 \mu \mathrm{W} / \mathrm{cm}^{2} / \mathrm{nm}$ ) in clear glass vials. Current activity measurements are performed in amber vials in the dark. The present results were obtained with metalloporphyrin solutions containing human serum albumin. The presence of albumin was determined to have no effect on the efficacy of metalloporphyrins as HO inhibitors, but it facilitates the preparation of homogenous solutions of metalloporphyrins at physiologic pH. Furthermore, our introduction of ethanolamine as a solvent has greatly facilitated the solubilization of metalloporphyrins, and addition of human serum albumin with the procedure of slow and gradual $\mathrm{pH}$ titration now yields clear solutions of $\mathrm{pH}$ 7.4-7.6.

The results of SnPP's interaction with intestinal $\mathrm{HO}$ in vitro are puzzling. Unlike liver and spleen preparations, the intestinal enzyme does not seem to be sensitive to increasing concentrations of SnPP and SnMP. Intestinal HO activity was only incom- 
pletely inhibited by $100 \mu \mathrm{M}$ SnPP or $10 \mu \mathrm{M}$ SnMP to $42 \%$, and $26 \%$ of control activity, respectively. Thus, our findings suggest that the intestinal enzyme seems to be of a different nature (or at least behaves differently under our current standard reaction conditions) than its hepatic and splenic analogues where generally more complete and concentration dependent inhibition of HO activity by SnPP and SnMP was observed. Additionally, these findings show the zinc compounds, $\mathrm{ZnPP}$ and $\mathrm{ZnMP}$, to be more potent inhibitors of in vitro intestinal $\mathrm{HO}$ activity than the corresponding tin compounds. The reverse is usually true for other tissue preparations.

The validity of the CO-based determination $\mathrm{HO}$ activity assay could be questioned if the presently used blank would not adequately correct for non-HO generated $\mathrm{CO}$. In vivo experiments have estimated that only $10-20 \%$ of the evolved $\mathrm{CO}$ is derived from nonheme degrading processes (30). Our in vitro blank values originate in part $(<5 \%)$ from $\mathrm{CO}$ generated by the reaction vessel septum. The major portion, however, is derived from as yet unidentified dark reactions in the tissue preparation, at rates which are tissue-dependent (liver $<$ spleen $<$ intestine) (23). This non-HO-mediated $\mathrm{CO}$ production, determined by the blank reaction, is subtracted from the total $\mathrm{CO}$ production in the presence of NADPH to obtain the HO-mediated CO production rate. The blank rates (measured in the dark) for any of the tissues are not significantly affected by the presence of metalloporphyrins at any concentration. Only $\mathrm{CO}$ production due to the presence of NADPH (by definition $\mathrm{HO}$ activity) is decreased by the presence of metalloporphyrins. The $\mathrm{HO}$-mediated $\mathrm{CO}$ generation in the dark becomes nondetectable for spleen and is reduced to approximately $20 \%$ of native activity for the liver at the highest metalloporphyrin concentrations. This is strong, though indirect evidence, that the $\mathrm{CO}$-based $\mathrm{HO}$ activity assay measures true $\mathrm{HO}$ activity.

Light affects $\mathrm{CO}$ production by tissue preparations, even in the absence of added photosensitizers as can be seen in Table 2. The magnitude of this phenomemon is tissue dependent and is most likely due to the presence of endogenous photosensitizers such as riboflavin (31) which, like SnPP, also produce $\mathrm{CO}$ from organic molecules such as NADPH and proteins (Vreman HJ, Stevenson DK, unpublished data). This potential source of error is also prevented by performing the $\mathrm{HO}$ activity assay in the dark.

In conclusion, our results indicate that the central metal within the porphyrin ring and substituents on the ring appear to play a crucial role in the inhibitory potency of metalloporphyrins on $\mathrm{HO}$ activity, which may vary from tissue to tissue. Moreover, HO behaves differently from tissue to tissue under varying experimental conditions of inhibition and light exposure. Finally, light significantly affects the biochemical behavior of metalloporphyrins.

\section{REFERENCES}

1. Tenhunen R, Marver HS, Schmid R 1968 The enzymatic conversion of heme by microsomal heme oxygenase. Proc Natl Acad Sci USA 61:748-755

2. Sassa S, Drummond GS, Bernstein SE, Kappas A 1983 Tin-protoporphyrin suppression of hyperbilirubinemia in mutant mice with severe hemolytic anemia. Blood 61:1011-1013

3. Kappas A, Drummond GS, Simionatto CS, Anderson KE 1984 Control of heme oxygenase and plasma levels of bilirubin by a synthetic heme analog, tin-protoporphyrin. Hepatology 4:336-341
4. Cornelius CE, Rodgers PA 1984 Prevention of neonatal hyperbilirubinemia in Rhesus monkeys by tin-protoporphyrin. Pediatr Res 18:728-738

5. Anderson KE, Simionatto CS, Drummond GS, Kappas A 1986 Disposition of tin-protoporphyrin and suppression of hyperbilirubinemia in humans. Clin Pharmacol Ther 39:510-520

6. Maines MD 1981 Zinc-protoporphyrin is a selective inhibitor of heme oxygenase activity in the neonatal rat. Biochem Biophys Acta 673:339-350

7. Maines MD, Veltman JC 1984 Phenylhydrazine-mediated induction of haem oxygenase activity in rat liver and kidney and development of hyperbilirubinemia. Inhibition by zinc-protoporphyrin. Biochem J 217:409-417

8. Qato MK, Maines MD 1985 Prevention of neonatal hyperbilirubinemia in non-human primates by Zn-protoporphyrin. Biochem J 226:51-57

9. Drummond GS, Kappas A 1981 Prevention of neonatal hyperbilirubinemia by tin-protoporphyrin IX, a potent competitive inhibitor of heme oxidation. Proc Natl Acad Sci USA 78:6466-6470

10. Yoshinaga T, Sassa S, Kappas A 1982 Purification and properties of bovine spleen heme oxygenase. Amino acid composition and sites of action of inhibitors of heme oxidation. J Biol Chem 257:7778-7785

11. Drummond GS, Galbraith RA, Sardana MK, Kappas A 1987 Reduction of the $C_{2}$ and $C_{4}$ vinyl groups of $S n$-protoporphyrin markedly enhances the ability of metalloporphyrin to inhibit in vivo heme catabolism. Arch Biochem Biophys 255:64-74

12. Hamori CJ, Vreman HJ, Stevenson DK 1989 Suppression of carbon monoxide excretion by zinc mesophorphyrin in adult Wistar rats: evidence for potent in vivo inhibition of bilirubin production. Res Commun Chem Pathol Pharmacol 62:41-48

13. Kappas A, Simionatto CS, Drummond GS, Sassa S, Anderson KE 1985 The liver excretes large amounts of heme into bile when heme oxygenase is inhibited competitively by Sn-protoporphyrin. Proc Natl Acad Sci USA 82:890-900

14. Hintz SR, Kwong LK, Vreman HJ, Stevenson DK 1987 Recovery of exogenous heme as carbon monoxide and biliary heme in adult rats after tin protoporphyrin. J Pediatr Gastroenterol Nutr 6:302-306

15. Raffin SB, Woo CH, Roost KT, Price DC, Schmid R 1982 Intestinal absorption of hemoglobin iron-heme cleavage by mucosal heme oxygenase. J Clin Invest 70:23-29

16. Correia MA, Schmid R 1975 Effect of cobalt on microsomal cytochrome P450: differences between liver and intestinal mucosa. Biochem Biophys Res Commun 65:1378-1384

17. Hartmann F, Bissell DM 1982 Metabolism of heme and bilirubin in rat and human small intestinal mucosa. J Clin Invest 70:23-29

18. Hintz SR, Kim CB, Vreman HJ, Stevenson DK 1988 Lack of inhibition of intestinal heme oxygenase by antibiotics and tin protoporphyrin. Pediatr Res 23:50-53

19. Kuipers F, Havinga R, Bosschieter $H$, Toorop GP, Hindriks FR, Vonk RJ 1985 Enterohepatic circulation in the rat. Gastroenterology 88:403-411

20. Kim CB, Hintz SR, Vreman HJ, Stevenson DK 1988 In vitro carbon monoxide production by the small intestine of suckling and adult Wistar rats: effect of parenteral tin protoporphyrin. Dev Pharmacol Ther 11:166-172

21. Vreman HJ, Hintz SR, Kim CB, Stevenson DK 1988 Effects of oral administration of tin- and zinc-protoporphyrin on neonatal and adult rat tissue heme oxygenase acitivity. J Pediatr Gastroenterol Nutr 7:902-906

22. Maines MD, Trakshel GM, Kutty RK 1986 Characterization of two constitutive forms of rat liver microsomal heme oxygenase. J Biol Chem 261:411419

23. Vreman HJ, Stevenson DK 1988 Heme oxygenase activity as measured by carbon monoxide production. Anal Biochem 168:31-38

24. Vreman HJ, Downum KR, Stevenson DK 1988 Generation of CO by tin protoporphyrin as a function of light exposure. Pediatr Res 23:265A(abstr)

25. Lowry OH, Rosebrough HJ, Farr AL, Randall RJ 1951 Protein measurement with Folin phenol reagent. J Biol Chem 193:264-275

26. Delaney JK, Mauzerall D, Drummond GS, Kappas A 1988 Photophysical properties of Sn-porphyrins: Potential clinical importance. Pediatrics 81:498-504

27. Scott J, Quirke JME, Downum KR, Vreman HJ, Stevenson DK 1988 Phototoxicity of metalloporphyrins. Photochem Photobiol 27:785(abstr)

28. Land EJ, McDonagh AF, McGarvey DJ 1988 Photophysical studies of tin(IV)proto-porphyrin: potential phototoxicity of a chemotherapuetic agent proposed for the prevention of neonatal jaundice. Proc Natl Acad Sci USA 85:5249-5253

29. McDonagh AF, Palma LA 1985 Tin-protoporphyrin: a potent photosensitizer of bilirubin destruction. Photochem Photobiol 42:261-264

30. Bissell DM, Guzelain PS 1980 Degradation of endogenous hepatic heme by pathways not yielding carbon monoxide. J Clin Invest 65:1135-1140

31. Sanvordeker DR, Kostenbauder HB 1974 Mechanism of riboflavin enhancement of bilirubin photodecomposition in vitro. J Pharmacol Sci 63:404-408 